\title{
ANALISIS KESALAHAN SISWA KELAS X IPA 1 SMAN 2 PEKANBARU DALAM MENYELESAIKAN SOAL PERTIDAKSAMAAN RASIONAL DAN IRASIONAL
}

\author{
Gema Raufany ${ }^{1)}$, Titi Solfitri ${ }^{2}$ \\ ${ }^{1)}$ SMA Smart Indonesia Pekanbaru \\ ${ }^{2}$ Pendidikan Matematika, Universitas Riau \\ Email : gemaraufany95@gmail.com
}

\begin{abstract}
This study aimed to determine students' mistakes in solving mathematics problems on the rational and irrational inequality of one variable. This research is a qualitative descriptive study. The research subjects consisted of 36 students consisting of 17 boys and 19 girls. The research instrument used was a learning achievement test consisting of three items that referred to Basic Competence (KD) 3.2 Explain and determine the resolution of rational and irrational inequalities of one variable. From KD 3.2 developed into three Indicators of Competency Achievement (IPK). Each item measures a different IPK. Students' answers were analyzed descriptively qualitatively by looking at the types of mistakes students made on each item. The results showed that the mistakes made by students were concept errors, principle errors, and operating errors. The mistakes made by students are caused by students not being careful in solving problems and not understanding the rules of algebraic operations.
\end{abstract}

Keywords : Student's error analysis, Rational inequality, Irrational inequality

\section{PENDAHULUAN}

Matematika merupakan mata pelajaran yang mempunyai peranan yang sangat penting bagi siswa, karena matematika berfungsi untuk mengembangkan kemampuan berkomunikasi dengan simbol-simbol serta ketajaman penalaran yang dapat memperjelas dan menyelesaikan permasalahan yang terjadi dalam kehidupan sehari-hari. Melalui pembelajaran matematika, siswa diharapkan dapat menumbuhkan kemampuan berpikir kritis, logis, sistematis, cermat, efektif, dan efisien dalam memecahkan masalah.

Tercapainya tujuan pembelajaran matematika dapat dilihat dari keberhasilan siswa dalam memahami matematika dan memanfaatkan pemahaman tersebut untuk menyelesaikan permasalahan matematika. Oleh karena itu, perlu dilakukan evaluasi atau tes hasil belajar siswa untuk mengukur kemampuan yang dimiliki siswa terhadap suatu materi tertentu. Dari hasil evaluasi dapat diketahui sejauh mana keberhasilan proses pembelajaran dan letak kesalahan siswa. Evaluasi yang diberikan kepada siswa biasanya berupa pemberian soal-soal matematika, baik soal rutin maupun soal nonrutin.

Pada kenyataannya, banyak siswa yang mengeluh karena mengalami kesulitan dalam memahami soal-soal matematika sehingga siswa seringkali melakukan kesalahan dalam menyelesaikan soal-soal yang diberikan guru.

Banyaknya kesalahan yang dilakukan siswa dalam mengerjakan soal matematika bisa menjadi petunjuk sejauh mana penguasaan siswa terhadap materi matematika. Dari kesalahan yang dilakukan siswa dapat diteliti dan dikaji lebih lanjut mengenai sumber kesalahan siswa. Sumber kesalahan yang dilakukan siswa harus segera mendapat pemecahan yang tuntas karena siswa akan selalu mengalami kesulitan jika kesalahan sebelumnya tidak diperbaiki terutama soal yang memiliki karakteristik yang sama. Hal ini sejalan dengan pendapat Rusdianto (2010) yang menyatakan bahwa manfat menganalisis kesalahan adalah sebagai sarana peningkatan pembelajaran untuk materi tertentu dan menumbuhkembangkan wawasan baru bagi guru dalam melaksanakan pembelajaran guna mengatasi kesulitan siswa dalam belajar.

Menganalisis kesalahan siswa dalam menyelesaikan permasalahan matematika sangat penting dilakukan karena ciri utama matematika adalah penalaran deduktif, yaitu kebenaran suatu konsep atau pernyataan merupakan akibat logis dari kebenaran sebelumnya, sehingga kaitan antar konsep atau pernyataan dalam matematika bersifat 
konsisten. Belajar matematika merupakan suatu proses yang berkesinambungan untuk memperoleh konsep, ide, dan pengetahuan baru yang berdasarkan pengalamanpengalaman sebelumnya. Oleh karena itu, untuk setiap materi matematika, siswa diharapkan benar-benar menguasai suatu konsep karena konsep tersebut akan digunakan untuk mempelajari materi matematika berikutnya. Materi matematika yang diajarkan di Sekolah Dasar (SD) akan dilanjutkan di Sekolah Menengah Pertama (SMP) yang kemudian akan digunakan di Sekolah Menengah Atas (SMA).

Salah satu materi yang diajarkan pada kelas X SMA berdasarkan Kurikulum 2013 adalah Pertidaksamaan Rasional dan Irasional Satu Variabel. Materi ini merupakan bidang aljabar yang melibatkan prinsip penyelesaian tertentu dan banyak menggunakan aturan operasi aljabar. Pada materi ini, biasanya siswa hanya mengerjakan soal secara prosedural sesuai contoh yang diberikan guru tanpa memahami dengan baik prinsip penyelesaian pertidaksamaan rasional dan irasional dan penerapannya dalam penyelesaian masalah. Hal ini menyebabkan siswa banyak melakukan kesalahan dalam menyelesaikan soal.

Menurut Soedjadi (2000), kesalahan siswa dalam menyelesaikan soal matematika dapat dibedakan menjadi empat, yakni kesalahan fakta, kesalahan konsep, kesalahan prinsip, dan kesalahan operasi. Kesalahan fakta adalah kesalahan dalam menuliskan konvensi-konvensi yang dinyatakan dengan simbol-simbol matematika, seperti kesalahan dalam membuat model matematika dari suatu permasalahan, kesalahan dalam menginterpretasikan hasil yang didapat, dan kesalahan dalam menuliskan simbol-simbol matematika. Kesalahan konsep adalah kekeliruan dalam menggolongkan atau menglarifikasikan sekumpulan objek. Konsep yang dimaksud dalam matematika dapat berupa definisi. Contoh kesalahan konsep antara lain kesalahan dalam menggolongkan apakah suatu relasi merupakan suatu fungsi. Kesalahan prinsip adalah kekeliruan dalam beberapa fakta atau beberapa konsep, seperti kesalahan dalam menggunakan rumus atau teorema serta kesalahan dalam menggunakan prinsip-prinsip sebelumnya. Sedangkan kesalahan operasi adalah kekeliruan dalam pengerjaan hitung, pengerjaan aljabar, dan pengerjaan matematika yang lain. Contoh kesalahan operasi adalah kesalahan dalam menjumlahkan, mengurangkan, dan kesalahan dalam operasi matematika lainnya.

\section{METODE}

Penelitian ini merupakan penelitian deskriptif kualitatif yang bertujuan mengungkap secara cermat kesalahankesalahan siswa dalam menyelesaikan soal Pertidaksamaan Rasional dan Irasional Satu Variabel. Penelitian kualitatif adalah suatu penelitian yang ditujukan untuk mendeskripsikan dan menganalisis fenomena, peristiwa, aktifitas sosial, sikap, kepercayaan, persepsi, pemikiran, orang secara individual maupun kelompok (Sukmadinata, 2009).

Penelitian ini dilaksanakan di SMA Negeri 2 Pekanbaru. Subjek penelitian ini adalah siswa kelas X IPA 1 yang berjumlah 36 orang. Siswa laki-laki berjumlah 17 orang dan siswa perempuan berjumlah 19 orang. Instrumen penelitian yang digunakan adalah tes hasil belajar yang terdiri dari tiga butir soal yang mengacu kepada Kompetensi Dasar (KD) 3.2 Menjelaskan dan menentukan penyelesaian pertidaksamaan rasional dan irasional satu variabel. Dari KD 3.2 dikembangkan menjadi tiga Indikator Pencapaian Kompetensi (IPK). Masingmasing butir soal mengukur satu IPK yang berbeda. Hasil jawaban siswa dianalisis secara deskriptif kualitatif dengan melihat jenis kesalahan yang dilakukan siswa pada setiap butir soal.

\section{HASIL DAN PEMBAHASAN}

Pelaksanaan tes dilakukan pada hari Senin tanggal 21 Agustus 2017 bertepatan dengan pelaksanaan Ulangan Harian. Berikut ini dipaparkan kesalahan-kesalahan yang dilakukaan siswa pada setiap IPK.

1. IPK: Menentukan himpunan penyelesaian dari pertidaksamaan rasional yang memuat fungsi linear satu variabel

1. Tentukan himpunan penyelesaian dari $\frac{6 x-1}{x+3}>1$.

Gambar 1. Soal Nomor 1 
PRINSIP Pendidikan Matematika

Volume 2, Nomor 1, November 2019

Pada Gambar 1 dapat dilihat bahwa siswa diminta untuk menentukan himpunan penyelesaian dari pertidaksamaan rasional yang memuat fungsi linear satu variabel. Sebagian besar siswa telah mampu melakukan langkah-langkah penyelesaian pertidaksamaan rasional dengan baik. Kesalahan yang dilakukan siswa dalam menjawab soal nomor 1 adalah kesalahan operasi dan kesalahan konsep. Siswa melakukan kesalahan saat menentukan nilai pembuat nol sehingga hasil akhir yang didapat juga salah.Kesalahan yang dilakukan siswa untuk soal nomor 1 dapat dilihat pada Gambar 2.

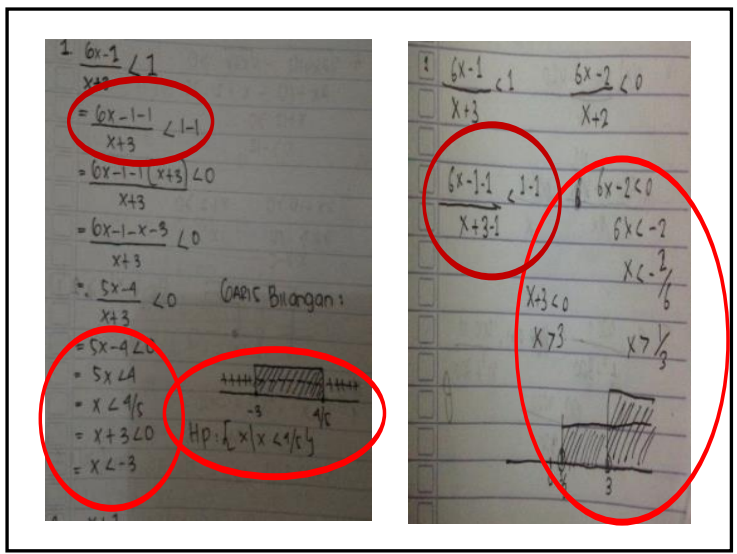

Gambar 2. Contoh Kesalahan Operasi dan Kesalahan Konsep pada Soal Nomor 1

2. IPK : Menentukan himpunan penyelesaian dari pertidaksamaan rasional yang memuat fungsi kuadrat

2. Tentukan himpunan penyelesaian dari $\frac{x+1}{x^{2}+4 x-5} \geq 0$

Gambar 3. Soal Nomor 2

Soal nomor 2 seperti terlihat pada Gambar 3 mengukur kemampuan siswa dalam menentukan himpunan penyelesaian dari pertidaksamaan rasional yang memuat fungsi kuadrat. Sebagian besar siswa telah melakukan penyelesaian pertidaksamaan dengan baik. Kesalahan yang dilakukan siswa dalam menjawab soal nomor 2 adalah kesalahan konsep seperti yang dapat dilihat pada Gambar 4.

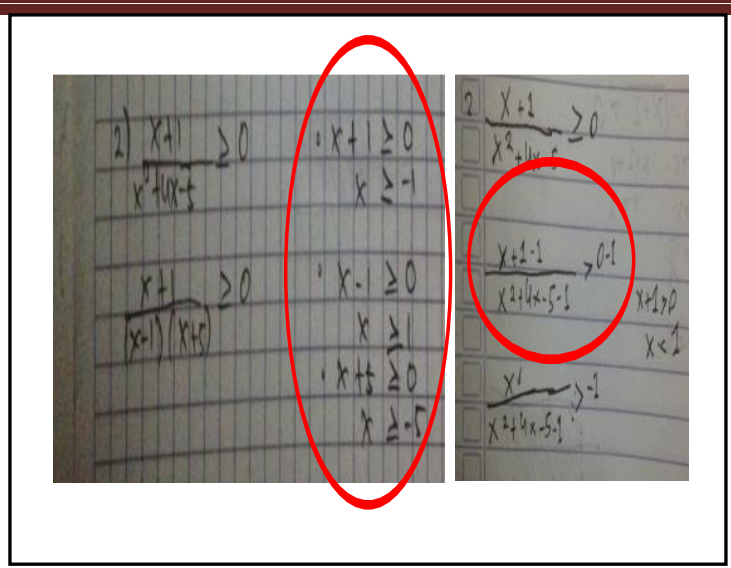

Gambar 4. Contoh Kesalahan Konsep pada Soal Nomor 2

Pada Gambar 4 dapat dilihat bahwa siswa melakukan kesalahan saat menentukan nilai pembuat nol. Siswa juga melakukan kesalahan pada operasi hitung, yaitu saat mengurangi ruas kiri, pembilang dan penyebut dengan 1 , seharusnya siswa memfaktor fungsi kuadrat dan mencari nilai pembuat nol.

3. IPK : Menentukan himpunan penyelesaian dari pertidaksamaan irasional

3. Tentukan himpunan penyelesaian dari

$$
\sqrt{2 x+10}-\sqrt{x+2}>0
$$

Gambar 5. Soal Nomor 3

Pada Gambar 5 dapat dilihat bahwa siswa diminta untuk menentukan himpunan penyelesaian dari pertidaksamaan irasional (bentuk akar). Kesalahan yang dilakukan siswa dalam menjawab soal nomor 3 adalah kesalahan prinsip. Pada Gambar 6a, kesalahan yang dilakukan siswa adalah langsung menguadratkan ruas kiri dan kanan. Seharusnya sebelum dikuadratkan, pertidaksamaan harus diubah ke dalam bentuk $f(x)>g(x)$. Pada Gambar 6b dan 6c, kesalahan yang dilakukan siswa adalah tidak menghilangkan tanda akar sebagai langkah pertama. 
PRINSIP Pendidikan Matematika

Volume 2, Nomor 1, November 2019

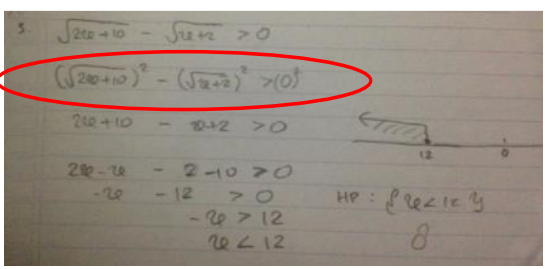

(a)

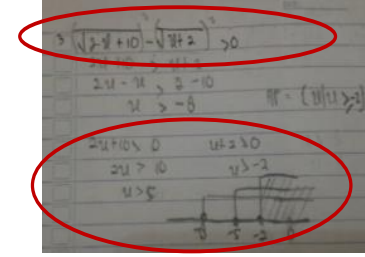

(b)

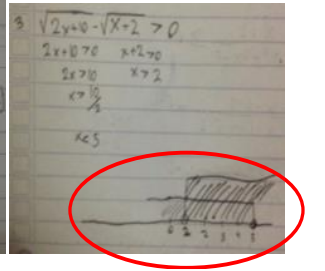

(c)
Gambar 6. Contoh Kesalahan Prinsip pada Soal Nomor 3

Dari tiga soal yang diberikan kepada siswa, masih terdapat kesalahan yang dilakukan siswa untuk masing-masing soal. Kesalahan ini tidak terlepas dari berbagai faktor penyebab jika ditinjau dari kesulitan dan kemampuan belajar siswa seperti yang dipaparkan oleh Rusdianto (2010), antara lain: (a) Kurangnya pemahaman siswa terhadap materi prasyarat baik sifat, rumus, dan prosedur pengerjaan; (b) Kurangnya minat terhadap pelajaran matematika atau ketidakseriusan siswa dalam mengikuti pelajaran; (c) Siswa tidak belajar walaupun mengetahui adanya tes atau ulangan; (d) Lupa rumus yang akan digunakan untuk menyelesaikan soal; (e) Salah dalam memasukkan data; (f) Tergesa-gesa dalam menyelesaikan soal; dan (g) Kurang teliti dalam menyelesaikan soal.

\section{SIMPULAN}

Berdasarkan hasil penelitian dan pembahasan dapat disimpulkan bahwa kesalahan siswa kelas X IPA 1 SMA Negeri 2 Pekanbaru dalam mengerjakan soal pertidaksamaan rasional dan irasional adalah kesalahan operasi, konsep, dan prinsip. Kesalahan-kesalahan yang dilakukan siswa disebabkan karena siswa tidak teliti dalam menyelesaikan soal dan kurang memahami aturan operasi aljabar.

\section{REKOMENDASI}

Berdasarkan faktor penyebab dari kesalahan yang dilakukan siswa, maka peneliti mengajukan rekomendasi yang berhubungan analisis kesalahan siswa pada materi pertidaksamaan rasional dan irasional, yaitu hendaknya guru lebih memperdalam pemahaman materi prasyarat siswa dan guru lebih membiasakan siswa untuk menyelesaikan soal dengan langkah-langkah penyelesaian yang lengkap seperti menyederhanakan pecahan bentuk aljabar.

\section{DAFTAR PUSTAKA}

Kemendikbud. (2014). Salinan Lampiran Permendikbud No. 58 Tahun 2014 Tentang Kurikulum 2013 Sekolah Menengah Pertama/Madrasah Tsanawiyah. Jakarta: Kemendikbud.

Kemendikbud. (2016). Salinan Lampiran Permendikbud No. 23 Tahun 2016 Tentang Standar Penilaian Pendidikan. Jakarta: Kemendikbud.

Rusdianto, H.D. 2010. Analisis Kesalahan Siswa Kelas VII-G SMPN 1 Tulangan Sidoarjo dalam Menyelesaikan Masalahmasalah Perbandingan Bentuk Soal Cerita. UIN Sunan Ampel Surabaya: 1027. [Online]. Tersedia: http://digilib.sunanampel.ac.id/files/disk1/198/jiptian-nanikzaini-988-5-bab2.pdf. (1 Maret 2014).

Soedjadi, R. (2000). Kiat Pendidikan Matematika di Indonesia Konstatasi Keadaan Masa Kini Menuju Harapan Masa Depan. Jakarta: Dikjen Dikti Depdiknas.

Sukmadinata, N.S. (2009). Metode Penelitian Pendidikan. Bandung: Remaja Rosdakarya. 